\title{
A REPORT ON THE MONTEVIDEO CONFERENCE AND CREDITOR DISCRIMINATION
}

\author{
By Kurt H. Nadelmann $\dagger$
}

With the Seventh Inter-American Bar Conference, held recently in Montevideo, another chapter in the long story of discrimination against foreign creditors in Latin America has come to a close. The last act of this story has still to be written, and, as things stand now, the status quo has a good chance of reaching the first centenary of its existence. It all started in 1857 when Eduardo Acevedo of Uruguay and Dalmacio Velez Sarsfield of Argentina included in their draft of a commercial code for the Province of Buenos Aires a provision to the effect that, when bankruptcy is declared within the country and abroad, in the domestic bankruptcy the creditors within the country shall be paid in full before creditors of the foreign bankruptcy may take part in the distributions. The provision became the law of Argentina and passed also into the law of Uruguay, Paraguay, and Peru. The source from which the drafters took the rule is unknown, and it has never been satisfactorily explained why the priority should be limited to concurrent bankruptcies if there was to be priority at all. The provision is still in the codes. ${ }^{1}$

South America can claim the production of the first multipartite agreement on conflict of laws, the treaties of Montevideo of $1889 .{ }^{2}$ The treaty of 1889 on International Commercial Law includes rules on conflicts in bankruptcy. ${ }^{3}$ Under these rules, drafted by the Uruguayan jurist Gonzalo Ramirez, if assets are in more than one country, local creditors may ask for a local adjudication. In the local bankruptcy the local creditors are paid first. Local creditor is defined as a creditor with a claim payable within the country. A place-ofpayment priority thus replaced the priority based on residence. Why the place of payment should justify differentiation between unsecured

† J. U. D., Freiburg in Breisgau, 1921; Lic. en Dr., Paris, 1934. Chairman, Special Committee on Conflict of United States and Foreign Law, National Bankruptcy Conference. Lecturer, Inter-American Law Institute, New York University School of Law. Author of Creditor Equality in Inter-State Bankruptcies: A Requisite of Uniformity in the Regulation of Bankruptcy, 98 U. OF PA. L. REv. 41 (1949), and other articles in domestic and foreign legal periodicals.

1. Argentina: Bankruptcy Law No. 11,719 of $1933, \$ 7$ (2); Uruguay: Commercial Code, $\$ 1577$; Paraguay: Commercial Code, \$1383; Peru: Bankruptcy Law No. 7,566 of $1932, \S 26(2)$.

2. See Baldwin, The Comparative Results, in the Advancement of Private International Law, of the Montevideo Congress of $1888-9$ and the Hague Conferences of 1893, 1894, 1900, and 1904, 2 Ax. PoL. ScI. Ass'N ProceEdings 73 (1905).

3. English text in: Report of the International American Congress 876 (Washington, D.C., 1890). Cf. Nadelmann, Bankriptcy Treaties, 93 U. of PA. L. REv. 58, 69 (1944). 
claims was immediately questioned. The treaty of 1889 on International Civil Law has a similar rule for the payment of debts of solvent decedents. ${ }^{4}$ When the propriety of the rule in one treaty was challenged, reference was made to the rule in the other treaty; and it was pointed out that the domestic law of the treaty partners actually differentiated among unsecured claims, though on a more primitive basis.

The countries with the old place-of-residence priority rule have all become partners to the Montevideo treaty. They thus apply among themselves the refined place-of-payment priority and against the rest of the world the old priority based on residence. The old rule has lost all support, and a number of writers have openly advocated a change in the law. ${ }^{5}$ The rule appears, however, in official drafts of new laws published recently in Uruguay ${ }^{6}$ and Argentina. ${ }^{7}$ As for the place-of-payment priority, the Argentine Institute of International Law made an attempt in the Nineteen Thirties to have the whole priority system eliminated from the Montevideo treaties, but Uruguay not only insisted on continuation of the system but asked for extension of the priority to cases where no local bankruptcy is declared although assets are in several countries. ${ }^{8}$ The new Montevideo treaties of 1940 actually embodied this extension of the priority, but the treaties have not been ratified and the extension is attacked even by Uruguayan authors. $^{9}$

In support of a priority for local claims one still hears the old argument made that credit is given in reliance on local assets. ${ }^{10}$ The

4. See, Nadelmann, Insolvent Decedents' Estates, 49 Micr. L. REv. 1129, 1145 (1951)

5. E.g., Ernesto Quesada, Estudios sobre quiebras 335 (Buenos Aires 1882); 2 Calvo, Droit International, No. 911 (5th ed. Paris 1896); Carlos Alberto Alcorta, Régimen internacional de la quiebra, 14 Jurisprudencia Argentina, Part: Doctrine, p. 130 (1924); reprinted in 2 Revista Argentina de Derecho Internacional 354 (1931), 4 Vico, Curso de Derecho Internacional Privado 34 (2d ed. Buenos Aires 1939); 2 Orione, Ley de Quiebras 331 (Buenos Aires 1935).

6. Anteproyecto de Código de Comercio, \$711(2) (1948).

7. Ley Nacional de Bancarrotas-Proyecto del Poder Ejecutivo, $\$ 16(2)$ (1950).

8. See Videla Aranguren, El Concurso Civil de Acreedores en el Congreso de Montevideo, 4 Revista Argentina de Derecho Internacional 214, \$ 30 (1941); Lazcano, Book Review, [1944] 3 Jurisprudencia Argentina, Part: Bibliography, p. 44.

9. E.g., Quintin Alfonsín, Quiebras-La Doctrina de Montevideo y los Tratados de 1889 y 1940, p. 135 (Montevideo 1943).

10. While the disposition of enemy assets and the treatment of private claims against the enemy owner of such local assets presents a special problem, an American creditor who finds himself barred in another country which pays such claims out of the local assets, but only to its own nationals and resident creditors, will hardly be satisfied with the following explanation, offered in support of Section 34 (a) of the Trading with the Enemy Act, as amended, 60 StaT. 925 (1945), 50 U.S.C. App. 34(a) (Supp. 1950): "Of course cases may exist where the property in one vesting jurisdiction is the only property of the debtor and the probability of the debtor acquiring any more property is so remote that the vesting of the property in that jurisdiction and the barring of a foreign creditor's claim will result in economic loss. This seems a non-proximate effect for which no special provision need be made." Maurer, Protection of Non-Enemy Interests in Enenty External Assets, 16 LAw \& 
argument need not be taken seriously at a time when assets move faster than the argument can be made and when the consequences of such a rule must be clear to any practical-minded person. Some doctrinists have argued that the rule is a consequence of the principle of territoriality. ${ }^{11}$ All kinds of meanings have been given to territoriality, and one may of course read into it whatever one pleases. Nevertheless, cutting the estate of an insolvent into pieces and assigning claims to pieces which are available locally, by accident or because the debtor wanted it, is a proposition certainly novel to many a territorialist. The authors who advance that view seem to see only two alternatives. Either the effects of a foreign domiciliary adjudication must be recognized everywhere, with the result that all assets are liquidated and distributed in one administration-which is the system of the Bustamante Code of Private International Law of 1928, adopted by fifteen Latin American states; ${ }^{12}$ or the effects of the foreign bankruptcy are ignored altogether, with the result that each administration is considered separate and that the local assets are used to satisfy local claims-which is the system of the Montevideo treaties. The third possibility which exists is not even mentioned, although applied in the common law countries and most countries of Continental Europe. Several administrations may take place, but for the purposes of paying the debts the estate is considered a unit. Equality among the creditors is preserved as far as possible: a creditor who has received a dividend in one administration must wait in other administrations until the other creditors have first received the same dividend which he obtained. This principle of equalization, with which the writers seem to be unfamiliar, is not an invention of recent date. Lord Mansfield mentioned it, ${ }^{13}$ and Chief Justice Marshall applied it in Harrison v. Sterry. ${ }^{14}$ It is in the

Contens. Pros. 407, 420 (1951). Great Britain has now decided to exclude from payment claims not due to a British person. Distribution of GERMAN ENEMY Property (No. 2) Order, §3(9), Statutory Instruments 1951, No. 1899. See on this question, Nadelmann, Local Enemy Assets and the Paris Agreement on Reparation, 40 AMr. J. INT'L. L. 813 (1946).

11. See the discussions at the Franco-Latin-American Legal Conference of 1948 on the experience with the Bustamante Code and the Treaties of Montevideo, 71 Bulletin Trimestriel de la Société de Législation Comparée 701, 881 (France 1948).

12. 4 Hudson, International Legislation 2340 (1931). Cf. Nadelmann, supra note 3 , at 70 .

13. In Rickards v. Hudson (1762), cited in Hunter v. Potts, 4 T. R. 182, 100 Eng. Rep. 962 (1791), as reported in Smith, Appeals to the Privy Council from the American Plantations 490 (1950).

14. 5 Cranch 289,302 (U.S. 1809). In that case the Court had under its control funds of the debtor which belonged neither to the bankruptcy declared in England nor to that declared in the United States. The Chief Justice said: "The dividends paid by the British assignees, and those made by the American assignees, being taken into consideration, this residuum is to be so divided between them as to produce equality between the respective creditors." 
Bankruptcy Act of $1898,{ }^{15}$ and one need only consult leading civilian writers ${ }^{16}$ to find that it is applied in civil law countries too.

The local priority applied to the detriment of creditors from abroad naturally creates serious risks for American businessmen who deal with countries having such a priority. A debtor may become bankrupt, here and abroad, and the American creditor loses his equal share in the assets abroad because of the local priority rule there in existence.

Efforts have been made in recent years at meetings of the InterAmerican Bar Association to do something about this situation. At the Third Inter-American Bar Conference, held in Mexico City in 1944, the question of the so-called local priorities was raised. ${ }^{17}$ The Fifth Conference, held in Lima, Peru, in 1947, was provided with a comparative survey of the law in the Americas on admission of claims in concurrent bankruptcies. ${ }^{18}$ The Conference passed a vote in favor of greater uniformity of the law. The Sixth Conference, held in Detroit, Michigan, in 1949, went a step farther. ${ }^{10}$ Unanimously, a resolution was adopted against differentiation in bankruptcy among unsecured claims, whether on the basis of residence or nationality, or on the basis of place of payment or place of contract. ${ }^{20}$ The Conference further resolved that a committee prepare a draft of a uniform law on the subject.

This committee, headed by the present writer, on which there served with him distinguished jurists from Argentina, Brazil, Chile, Mexico, Peru, and Uruguay, drafted a report for the Seventh InterAmerican Bar Conference, which took place in Montevideo in November, 1951. The report, reproduced in the Appendix, has as its basis the Detroit resolution and is limited to a statement and explanation of

15. U.S. Bankruptcy Act, \$65(d), 30 STAT. 564' (1898), 11 U.S.C. \$105(d) (1938). Cf. Nadelmann, The National Bankruptcy Act and the Conflict of Lawes, 59 HARv. L. REv. 1025, 1049 (1946).

16. See, e.g., 8 Lyon-Caen \& Renault, Traité de Droit Commercial 833 (5th ed. 1936) ; 3 Percerou, Des Faillites et Banqueroutes 272 (2d ed. 1938); 4 Niboyet, Traité de Droit International Privé Français 920 n. 2 (1947) ; Provinciali, Manuale di Diritto Fallimentare 72 (2d ed. 1951).

17. In the paper by Nadelmann, Paramount Problems in International Bankruptcy Law, 50 CoM. L.J. 7 (1945).

18. Nadelmann, Concurrent Bankruptcies and Creditor Equality in the Americas, 96 U. of PA. L. REv. 171 (1947), 22 ReFerees' J. 51 (1948), 25 Annuario di Diritto Comparato 105 (Italy 1950).

19. Papers were presented by Olive, Requisites of Uniformity in the Regulation of Bankruptcy and Business Failures, 54 CoM. L.J. 203 (1949); Nadelmann, Creditor Equality in Inter-State Bankruptcies: $A$ Requisite of Uniformity in the. Regulation of Bankruptcy, 98 U. of PA. L. REv. 41 (1949), 2 Boletín del Instituto de Derecho Comparado de Mexico, No. 5, p. 65, 55 Revista Jurídica Argentina La Ley 1028 (1949).

20. Text in 98 U. of PA. L. Rev. 41, note (1949). 
the equalization rule. The similarity of the text with provisions in the Restatement of Confict of Lawes will be noticed. ${ }^{21}$ Respecting branches of foreign corporations, a reservation is made. Some countries grant branch creditors priority on local assets. ${ }^{22}$ It was felt that such a priority, if clearly stated in the law, is not objectionable on principles of bankruptcy law and that the desirability of such a priority is a question of policy not within the jurisdiction of the committee.

All members of the committee but one, the member from Uruguay, signed the committee report. The Uruguayan member dissented with the explanation that he disapproved of the part of the Detroit Resolution directed against the place-of-payment priority.

At the Montevideo Conference the report came before the committee on private international law. ${ }^{23}$ The report was briefly discussed, together with two other reports on the subject, one of them by the Philadelphia Bar Association ${ }^{24}$ and the other by a lawyer from Argentina who backed the Detroit Resolution. ${ }^{25}$ In accord with a recommendation in the report of the committee headed by the present writer, a resolution was drafted suggesting that the report be transmitted to the Inter-American Juridical Committee in Rio de Janeiro. A request was added that the Rio Committee undertake the study of conflicts in bankruptcy. It was further recommended that the committee of the Association be continued for possible assistance to the Rio Committee. This resolution was passed unanimously by the Conference. ${ }^{26}$ It should be noted that no vote was taken on the report. Had the question of approval of the report been pressed, the dissent and the local backing of the Montevideo treaty would in all probability have blocked approval, although the report as such only states the equalization rule which should not be a controversial matter.

The Inter-American Juridical Committee, to which the report will be sent, is the permanent committee of the Inter-American Council of Jurists, an organ of the Organization of American States. Our

21. Restatement, Conflict of Laws $\$ \S 501,502,558,559$ (1934).

22. Such priority exists, e.g., in Mexico: Bankruptcy Act of Dec. 31, 1942, $\S 13(3)$; Chile: Corporation Law No. 251, of May 20, 1931, § 123. For Brazil, see 3 Miranda Valverde, Comentarios a Lei de Falencias 141 (1949).

23. Minutes of the session held on November 23, 1951 by Committee II : Private International Law, published in the Journal of the Conference. The dissenting member from Uruguay was in the chair; none of the signers of the report were in attendance.

24. "Requisites of Uniformity in the Regulation of Bankruptcy and Business Failure, including Provisions for Non-Discrimination against Alien Creditors."

25. Francisco Orione, "Igualdad en el tratamiento de los acreedores en las quiebras internacionales. Unificación de la legislación respectiva."

26. Resolved (Nov. 30, 1951): "The VIIth Inter-American Bar Conference recommends: That problems arising from conflicts of laws regulating bankrupty in American countries be studied by the Inter-American Juridical Committee, and that papers on this subject, which were presented to this Conference, be sent by the Secretary General to the said Committee for their study and consideration. The Conference suggests: That the committee appointed in accordance with a resolution 
Government is represented on the Committee, as are eight other governments. The Council and the Committee are only beginning to function. At its first session, held recently, the Council instructed the Committee "to study the possibility of a revision of the Bustamante Code on Private International Law, to the extent that it might appear desirable, taking into account the treaties of Montevideo and the Restatement of Conflict of Laws, in order to reach uniformity of the three codifications." 27 Under this assignment, the Committee is actually asked, it would seem, to do what the Montevideo resolution requests it to do, bankruptcy being treated in the Bustamante Code. It remains to be seen whether and when the Rio Committee will take up bankruptcy and whether it will find that the bankruptcy part of the Bustamante Code should be revised. Whatever, if anything, may be attempted at Rio to deal with the local priorities, the difficulties likely to be encountered will be clear to the reader.

\section{III}

This report on a report will close with a few questions addressed to our Government. Aside from the question of protecting our creditors, is it considered advantageous to our prestige in Latin America to have the present situation continue indefinitely? The facts here recited are as known there as they are here. It is well known that in our country all creditors are treated alike and that the postponement of claims of our creditors in some Latin American countries is strongly resented. ${ }^{28}$ Is it "power politics" to ask the governments involved to bring an end to discrimination against our creditors? Is it not well understood Good Neighbor policy to see to it that causes of friction of this sort are removed?

The Montevideo treaty, which we have not signed and do not intend to sign, is not of our concern. We may leave discussion of the treaty to the treaty partners, who disagree among themselves on the wisdom of some of its principles. Our concern is the provision in the local laws which says that resident creditors shall be paid first in concurrent bankruptcies. This provision is unjust as such and par-

of the VIth Inter-American Bar Conference held in Detroit, to study the aforementioned problem, continue its work in order to offer its co-operation to the InterAmerican Juridical Committee.

27. Final Act of the First Meeting of the Inter-American Council of Jurists, Rio de Janeiro, May 22-June 15, 1950, pt. VII, 2, p. 16 (mim.), [1950] Inter-American Juridical Yearbook-; Note, The Inter-American Conncil of Jurists, 4 INT'L. L.Q. 521, 524 (1951).

28. The Detroit Resolution appeared in the Bulletin of the Mexican Institute of Comparative Law and in Revista Juridica Argentina La Ley, together with the paper presented by the present writer in Detroit: supra note 18. 
ticularly unfair if applied against creditors from the United States where all creditors are treated alike wherever they reside. The injustice of this particular situation is questioned nowhere in Latin America. Why then does our Government hesitate to suggest nonapplication of the provision against creditors from the United States?

In connection with the Point IV program, our Government has been engaged in the negotiation of new treaties of friendship and commerce to better protect our investments abroad. In pursuance of this policy, a new treaty was signed with Uruguay the $23 \mathrm{rd}$ of November, 1949. ${ }^{20}$ The treaty, we regret to say, does not provide protection against the provision in the commercial code of Uruguay that nonresident creditors shall be paid after the domestic in concurrent bankruptcies. For several years the National Bankruptcy Conference and the groups represented on the Conference have urged the Department of State to secure for our creditors equal treatment in Latin America. ${ }^{30}$ May it be asked why a new treaty was signed without taking care of this question?

Uruguay, model of democracy in Latin America, has been at all times in the best relations with the United States. Uruguay is presently engaged in the revision of its commercial code. The preliminary draft of a new commercial code published by the government in 1948 repeats, in Section 711(2), the old provision which says that in concurrent bankruptcies the domestic creditors shall be paid first. ${ }^{31}$ The opening words of the section: "Unless provided otherwise by treaty," are new though. In the report which accompanies the draft it is said in closing: "Official and private institutions, professors and practitioners, have an opportunity to express their views to correct deficiencies and the inevitable mistakes and to fill gaps where they exist." 32 Should we not express in the proper way our interest in Section 711(2) of the draft? As early as 1884, Uruguayans were told by one of their own that the rule is in complete opposition to modern findings of private international law. ${ }^{33}$ It seems to be the policy of Uruguay to wait until official protests come from abroad. We think that friendly overtures will be received there with due appreciation.

29. Text in 23 Dep't State Bull. 502 (1950). Senate advice and consent to ratification given on Aug. 9, 1950. Cf. 21 Dep'T. STAte Buld. 866a, 909 (1949).

30. E.g., National Bankruptcy Conference: 16 Dep'T. STAte Bul. 724 (1947); American Bar Association: 22 Referees' J. 118 (1948); Commercial Law League of America: 52 CoM. L.J. 89 (1947) ; Foreign Credit Interchange Bureau, National Association of Credit Men: 49 Credit \& Financial Management, No. 4, at 28 (1947).

31. Anteproyecto de Código de Comercio, supra, note 6.

32. At p. 361. (Our transiation).

33. Izcua Barbat, De la quiebra, 1 Revista de la Sociedad Universitaria 6, 148 (Uruguay 1884). 
APPENDIX.

VIIth Inter-American Bar Conference

Montevideo, 1951

Report

on a Model or Uniform Law

respecting Treatment of Creditors and Realization of Assets in Bankruptcies affecting Creditors domiciled and Property situated in different Countries.

Presented in execution of a Resolution of the VIth Inter-American Bar Conference

by the Committee appointed under the Resolution.

The VIth Inter-American Bar Conference, Detroit, 1949, resolved :

(1) That in bankruptcy, including the case of concurrent bankruptcies, no differentiation should be made between creditors on the basis of nationality, domicile, or place of residence;

(2) That in bankruptcy no differentiation should be made between unsecured claims on the basis of the place of contract or the place of payment;

(3) That a committee be appointed by the Executive Committee to draft a model uniform law which shall resolve the differences in the law as to the treatment of creditors and the realization of assets in bankruptcies affecting creditors domiciled and property situated in different countries; said committee to report at the next Conference.

The Executive Committee made the appointment provided for under (3) of the Resolution. Members of the committee appointed to draft the Uniform Law are:

Dr. Mauricio L. Yadarola, of Argentina,

Dr. Trajano de Miranda Valverde, of Brazil,

Dr. Raul Varela Varela, of Chile,

Dr. Roberto L. Mantilla Molina, of Mexico,

Dr. Hector J. Marisca, of Peru,

Dr. Kurt H. Nadelmann, of United States,

Dr. Quintin Alfonsin, of Uruguay. 
The committee was not able to meet. The report which follows was prepared by way of correspondence.

The administration of an insolvent estate with assets in various countries is likely to become difficult if distinct proceedings are conducted in several countries. Efforts which have been made to secure always a single administration have had but limited success. Many countries are without agreement with each other on the subject. Concurrent bankruptcies, consequently, are not infrequent. The law to govern in such situations is not uniform; often the law is uncertain. The report which follows is prepared with a view to clarifying the legal questions.

The report is based on the principle stated in the Resolution of the VIth Conference that all unsecured creditors shall be treated equally. The suggestions contained in this report are not directed toward situations where an agreement between specific countries regulates the subject on a different basis.

\section{II}

In concurrent bankruptcies the following rules should be observed:

(1) All creditors have the right to prove their claims in all administrations.

(2) As far as possible, each administration will dispose of the assets under its control in such a way that all creditors, wherever they prove their claims, receive an equal share in the whole estate of the debtor.

To that end the several administrations will exchange information on the available assets and the claims which have been proved. The total dividend available can then be determined and a scheme of payment worked out.

Observations. This system requires active cooperation of the administrations. In many cases cooperation has not been obtainable. Therefore express incorporation of the principle in the statutory law appears desirable.

(3) In each administration the admission of claims is governed by the local law, including its conflicts rules.

Consequently, questions of ranking of claims and of voidance of preferences are determined by the local law. Again the local 
law determines whether local proof is necessary, whether proof must be made by creditors individually, or whether the foreign trustee may prove for all claims admitted in his administration.

Observations. Because of differences in the law a claim may be subjected to different treatment in different administrations.

(4) The principle of equalization applies when a dividend has been allowed to a creditor in one administration and the creditor claims his share in another administration. This means that the creditor will not participate in the distributions in the second administration until the other creditors have first received the same dividend he has already obtained.

Observations. Equalization is applied also in cases where administrations do not cooperate. Application of the principle by all administrations leads to equal distribution of all assets among all creditors. As far as possible, equalization protects creditors who prove locally against possible unfair treatment of their claim abroad.

The principle of equalization resolves difficulties which may arise from differences in the law. For example, if a creditor is admitted in one country with a priority not recognized in the second country he will not share in the distributions in the second country until the other creditors have first received the percentage he has already obtained.

\section{III}

These rules furnish the basis for a uniform solution of the questions concerning admission of claims in concurrent bankruptcies. The Committee has not found it useful to elaborate the text of a uniform law; in view of the differences of systems and languages it has thought it preferable to leave to the respective legislatures the task of elaborating texts which incorporate the principles in the most appropriate way.

\section{IV}

The rules do not apply when the local law prescribes for the bankruptcy of branches of foreign corporations that the local assets shall be applied with priority to the payment of the creditors of the branch. The desirability of such a priority being controversial, the Committee has thought that it should abstain from passing judgment on that question. 
The Interamerican Council of Jurisconsults has recently decided to ask its permanent committee, the Interamerican Juridical Committee situated at Rio de Janeiro, to study the possibility of a revision of the Bustamante Code, to the extent that it might appear desirable, taking into consideration the Treaties of Montevideo and the American Restatement of the Law of Conflict of Laws, in order to reach uniformity of the three codifications.

As far as bankruptcy is concerned, the report which we present on the special question assigned to us, cannot fail to interest the Rio Committee. If our report is approved by the Conference, the Conference will no doubt take a decision on the question of a transmission of the Rio. Committee.

The members of our committee think that, insofar as bankruptcy is concerned, the question submitted to the Interamerican Juridical Committee should be examined by a special committee composed of specialists of the law of conflict of laws in matters of bankruptcy representing the three systems involved.

This Report has been approved by all committee members except Dr. Quintin Alfonsin who has expressed disagreement because of non-acceptance by him of Part (2) of the Detroit Resolution.

Cambridge, Massachusetts, the 21st of November, 1951.

KurT H. NadelmanN

Chairman, Committee on Uniform Conflicts Rules in Bankruptcy, Inter-American Bar Association 